Globalisation, Societies and Education

Vol. 8, No. 4, November 2010, pp.591-610

\title{
Education and conflict in Nepal: Possibilities for reconstruction
}

\author{
Tejendra J. Pherali
}

Liverpool John Moores University, United Kingdom

\begin{abstract}
This paper analyzes the nexus of 'People's War' and education in Nepal and argues that education was one of the main causes of the violent conflict. Despite 'modernization' efforts and increased participation, schools in Nepal continued to embody socially and culturally prejudiced values and institutionally legitimized the inequitable practices through the education system. Drawing on qualitative interviews with educational stakeholders from six diverse districts across the country, this paper shows how manifold deficiencies in the education system contributed to generate and fuel the 'ideology-led' Maoist rebellion and subsequently how schools thus became a key battlefield of the violent conflict.
\end{abstract}

Keywords: schools; education; conflict; peace-building; Nepal

\section{Introduction}

On 13 February 1996, a splinter faction of the large, diverse Communist Party of Nepal who proclaimed their ideas were inspired by Mao's peasant-led revolution in China (later known as simply the United Communist Party of Nepal, Maoist (UCPN-M)) announced a 'People's War' in Nepal by carrying out attacks on police posts in three districts: Rolpa and Rukum in the mid-west and Sindhuli in the east, instigating 'planned assaults' on two factories in Gorkha and Kathmandu and raiding the house of a civilian in the eastern district of Kavre (The Worker 1996). This war was initiated with the aim of overthrowing the constitutional monarchy and establishing 'a new socio-economic structure and state' (Bhattarai 2003; Maoist Statements \& Documents 2003). By the year 2002, the war had 
spread across the country engulfing 73 out of 75 districts claiming the deaths of approximately 8,000 people and causing enormous economic losses (Kumar 2003). Such a rapid expansion of the violent conflict is widely attributed to the extent of social inequality (Murshed and Gates 2005), the political failure or inefficiency of the government in addressing the insurgency at its early stage (Thapa 2003; Thapa and Sijapati 2004; Bohara, Mitchell, and Nepal 2006; Thapa and Sijapati 2004), and most importantly poverty (Deraniyagala 2005; Bhattarai 2003; Do and Iyer 2007). Before the Comprehensive Peace Accord (CPA) was signed eventually between the Government of Nepal and the CPN-M in November 2006, over 13,000 people had been killed along with irreversible social and economic damages to an all-ready strained social fabric and inadequate national infrastructure.

While there is a plethora of literature on the underlying causes of the Maoist rebellion (see Do and Iyer 2007; Hutt 2004; Thapa and Sijapati 2004; Kumar 2005), as well as some analysis of the educational context of the conflict in Nepal (Shields and Rappleye 2008a, 2008b), there is still a dearth of empirical studies which explore the impact of the decade-long violence on education. Most commonly rehearsed debates around the causes of conflict testify to the prevailing social, political and economic disparities in Nepali society, and more recently, some of the 'negative faces' of education (Shields and Rappleye 2008a) that form the backdrop to the uprising. However, three years after the CPA was signed, school education remains massively engulfed by the frictions and legacy of the 'People's War' and thus continues to struggle with both historical deficiencies of the system as well as the newly generated derivatives of violence.

In the context of contemplating the interplay between education and conflict, this article analyses the nexus of 'People's War' and education in Nepal and shows how education served obliquely as one of the main causes of the violent conflict. Despite efforts to 'modernize' and the push for increased participation in education, Nepalese schools continued to embody the socially and culturally prejudiced values and institutionally legitimized the inequitable practices in the education system. While the conflict seemingly began as a product of discontent sowed by the systematic injustice in Nepalese society, the paper also shows that the 'success' of the 'People's War' is equally attributed not only to the disadvantaged social groups who supposedly remained at the 
forefront of the uprising, but also to a large number of educated but highly frustrated youth and individuals from privileged backgrounds who 'envisioned', supported and even steered the rebellion. Drawing on qualitative interviews with educational stakeholders from six districts across the country, this article will show how multiple weaknesses in the education system contributed to generate and fuel the 'ideology-led' Maoist rebellion and subsequently how schools became a battlefield in the violent conflict. Finally, it will argue that post-conflict educational reconstruction needs to equally recognize both the underlying educational causes of the conflict and the detrimental impacts that the armed conflict has had on education.

\section{The 'People's War' and education in Nepal: some necessary background}

The nature of Nepal's Maoist rebellion has been broadly analyzed in ways that attribute its rationale to multifaceted political and sociological causes in Nepali society (Neupane 2003; Verma and Navlakha 2007; Maoist Statements \& Documents 2003). The CPN-M effectively mobilized the politically trained masses to expand their stronghold and intensify the 'People's War'. Educational settings, particularly schools, provided an opportunity for the Maoists to reach the country's young population through political training. The social and political agenda of the Maoists motivated young people who were profoundly uncritical of expedient political propaganda, yet perhaps predisposed to listen to revolutionary rhetoric because of the seemingly stagnant and unequal conditions that surrounded them. At the same time, threats, intimidation and brutal attacks on anyone noncompliant with the Maoist movement also created a state of terror across the country. Ideological indoctrination, political motivation and a perpetual state of fear collectively resulted in a rapid spread of the 'People's War'. School children and teachers were reported to have been frequently abducted by the rebels in order to put them through 'revolutionary training programs' (Pyakurel 2006, 55) or to be forcibly recruited in the Maoist militia (Watchlist 2005). It was also common to hear cases of extortion of money from teachers and calls on schools closure whenever the rebels saw fit (Simkhada 2006, $64)$. 
This should, by no means, deny the fact that a huge number of teachers and students voluntarily participated in the 'People's War' because Maoists' calls for fundamental change traveled well in the growing pockets of social stagnation, particularly in rural areas. The excessive media coverage of the abduction and abuse of educational professionals and children downplayed the reality that many of them actually believed that the 'People's War' was the only way of restoring social, political and economic justice to the country. Moreover, the reports on state-caused violence were mostly suppressed or underreported due to the military dominance during the 'emergency'. The security personnel arrested, tortured and even killed teachers and school children, who were suspected of being Maoist activists or sympathizers (Dhital 2006; Child Workers in Nepal Concerned Centre 2006; Sharma and Khadka 2006; Amnesty International 2005). As a result, teachers were often left with the conundrum - often one of life and death - of whether to implement the 'Maoist' or the 'national' curriculum in their classrooms, as well as what to say to students who asked about the conflict that increasingly surrounded them. The number of children abducted and tortured by the conflicting parties was reported to be several thousands, an indication that the armed conflict terrorized Nepali schools by bringing violence directly 'into' the educational sector; a phenomenon that has only been portrayed in passing in the literature to date (Sharma and Khadka 2006; Watchlist 2005; Hutt 2004; Thapa and Sijapati 2004).

Elsewhere, the student wing of the UCPN-M consistently demanded closure of all private schools accusing them of being merely commercial ventures rather than serving for social welfare. It is reported that more than 79 schools, one university and 13 district education offices were destroyed by the Maoists between the period of January 2002 and December 2006 (INSEC 2007), of which 32 were targeted by bomb explosions and at least 3 were caught in crossfire between the rebels and security forces (Child Workers in Nepal Concerned Centre 2006). Attacks on schools and their stakeholders particularly on teachers either for their non-compliance to 'compulsory donations' demanded by the rebels or their suspected complicit roles in the 'People's War' were reported almost every day in the Nepali media until the signing of the CPA ${ }^{\mathrm{i}}$. All of these different factors reveal that education played a central part in the conflict, a perspective that has not received 
nearly the attention from either scholars or development practitioners as it clearly warrants.

\section{An analytical framework for education and conflict}

Education and conflict is still a field of research in its 'infancy' (Tomlinson and Benefield 2005, 5) and the literature available is 'too thin' to incorporate the 'wide range of experiences' of conflict that education has retained in the fragile states (Sommers 2002, 2). However, the existing literature in this emerging field provides us with two intrinsically interconnected analytical frameworks: i) the role of education in preventing or fuelling violent conflict, and ii) the multifarious impacts of conflict on education. Of late, there has been an interesting debate both in academic and practitioners' literature about the complicit role of education in violent conflict (Bush and Saltarelli 2000; Davies 2004; Harber 2004). Davies (2005, 359) analyses the controversial role of education in terms of reproducing or hardening 'inequality, exclusion and social polarisation' and even 'legitimising inequality', a process that consequently amplifies 'social divisions' to exacerbate tensions in a society. Elsewhere, Bush and Saltarelli $(2000,9)$ examine the 'peace-building' and 'peace-destroying' role of education suggesting that education despite the idealism that surrounds it - can equally have 'socially destructive impact' unless its distribution, philosophy, curriculum and quality are scrutinized and ensured so that they explicitly serve the ends of social justice, equality and inclusive citizenship.

While the nexus of education and conflict in Nepal partially complies with this theoretical lens, there exist some new themes and explanations revealed by micro level analysis of the socio-cultural complexities, educational conditions and the political backdrop of the genesis and development of the 'People's War'. What emerges through this study is a deeper understanding of the contentious face of education, in particular, its role in producing educated 'masses' that were politically conscious and ideologically trained. These educated masses, instead of working for the cultivation of critical, positive and peaceful orientations in the process of social change, came to recognize armed rebellion as a legitimate means of eliminating the structures that perpetuate socio- 
economic disparities in Nepal. The agents of conflict in this case were ideologically extreme and could logically defend their views on the legitimacy of the use of violence. For them, attaining the goal (e.g. social, economic, political and cultural equalities) was paramount, justified their means, and motivated them to persist with the struggle. This ideological commitment and propagation of it to the wider populace, thus made schools a key 'battleground' in the conflict.

\section{Researching schooling and conflict: methodological issues}

This article draws on qualitative data collected as part of mixed methods, multilevel analysis research design (Silverman 2009). Eight schools, representing distinct geopolitical districts of Nepal (Doti, Rolpa, Kapilvastu, Kathmandu, Udaypur and Sankhuwasabha) $)^{\mathrm{ii}}$, were considered for the study, of which five were state-funded and three were private schools (Figure 1 below illustrates the regions where the study was conducted). School children from the most senior class (class 10 or 12) were asked to complete a 'narrative' writing task in which they described their experiences of the violent conflict (Clandinin and Connelly 2000). The parents of the students who had directly experienced some form of conflict were then invited to join in focus group discussions. Similarly, the teachers of each case school took part in a group activity in which they identified the conflict related incidents that occurred within or around the school and then reflected on how such incidents had impacted their own lives through similar focus group discussions. Headteachers from each school and the six District Education Officers representing six different districts were also directly interviewed. 


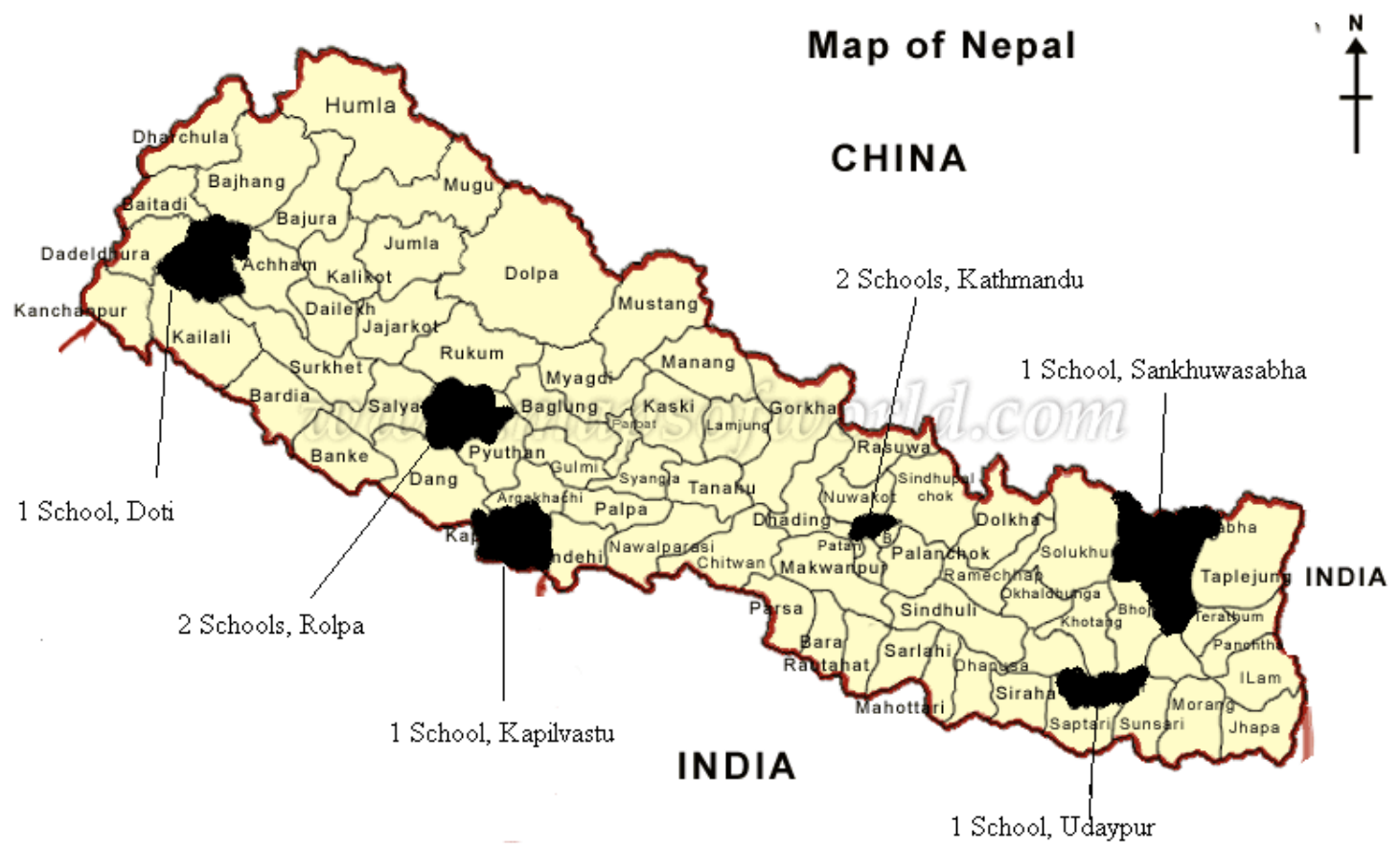

Figure 1: Political map of Nepal indicating research districts

\section{The complex 'face' of education in Nepal}

Education in Nepal is overwhelmingly seen and valued for its 'positive' and therefore, 'unquestionable' impact on social and economic well-being of people and the nation. At the same time, Shields and Rappleye (2008a, 93) note that the 'long history of social inequality and exclusion' in Nepal's education is hardly debatable and factored largely in the conflict. This lack of a critical take on education potentially overlooks the adverse effects that schooling can have on social cohesion (Tawil and Harley 2004). For this reason, Bush and Saltarelli (2000, 9-14) argue that education can play just as much of a 'negative' role in exacerbating hostility as 'positive': by extending prejudiced systems through the 'uneven distribution of education', utilizing 'education as a weapon in cultural repression', 'manipulating history for political purposes', 'manipulating textbooks' to influence feelings of 'self-worth and hating others', as well as segregating 'education to ensure inequality, lowered esteem and stereotyping'. Many of these 
qualities were and are evident in the historical development and present forms of Nepalese education.

Throughout the educational history of Nepal, this dark 'face' of education has rarely been scrutinized even while perpetuated by those who exercised power and (mis)used education as a tool to systematically achieve the unquestioning political compliance of the people. Even the oft celebrated contemporary 'success' of increased literacy rates and access to education (Central Bureau of Statistics 2003) overlooks the embedded values and principles of education and the existing discriminatory 'practices' in the educational settings. Children from Janajati and particularly the Dalit castes were and are still often treated unfairly at school and set minimal learning targets by teachers and administrators from the dominant caste and class groups, reflecting a historical predisposition that educational achievement was the exclusive domain of high-caste pupils. The curriculum intrinsically imparted and continues to convey prejudiced values of acceptance and conformity to the prevailing social and cultural hierarchy (Pigg 1992). For example, the atrocities caused by the Shah regime on various indigenous populations during and after the unification of Nepal are portrayed in the current history curriculum as acts of heroism. During the Panchayat era (1962-1990), this nationalized curriculum legitimized the 'autocratic power of the king' by adopting the 'theme of rajbhakti' (service to monarchy) (Onta 1996, 218) and children were made to celebrate the anniversaries of the royal family and join in the processions and chant slogans to show reverence to the Palace.

\section{Education for revolution}

Interestingly and importantly, the 'People's War' began not by those who were deprived of access to education but by a small proportion of those who were able to become educated and thus came to recognize the political opportunity to challenge the regime and 'the feudalistic structure of the state' (Bista 1991). That is, the idea of the 'communist revolution' in Nepal was born in the minds of generally educated people who mainly came from privileged backgrounds. They supposedly knew how to convert people's 
latent discontent rendered by the long-standing state negligence into the driver of rebellion. The Maoist leader, Pushpa Kamal Dahal (Prachanda) was born in an upper class Brahmin family and gained a university degree before working as a secondary school teacher. Similarly, Dr Babu Ram Bhattarai, the Vice Chairperson of the UCPN-M studied in a missionary school in Gorkha and obtained the top score in the national level School Leaving Certificate examination. Later, he went to Jawaharlal Nehru University, one of the most prestigious institutions in India to gain his doctorate in Regional Development and Planning. He had always been a top achiever throughout his academic and political career and is widely respected as an 'always first' man in Nepal. Interestingly, the average Nepali teacher is aware of these facts and thus has begun to make the connections between education, discrimination, development, and the conflict. As one school principal argued:

The 'people's war' was declared and led by some of the highly educated people. But, you must be aware that the 'People's War' began from Rolpa, a remote underdeveloped district. Why did it begin from Rolpa while the political movements in the history have started from urbanized or developed cities? Firstly, the dominant population of this region is Magar. Historically, the Magars have been always oppressed by the Brahmin oriented state structure of this country. This caste [Magar] is deprived of having opportunities to progress and have always been down trodden. The people from this caste are socially, politically and educationally deprived. They are very naïve and easily persuaded by other people. Secondly, Rolpa is much behind in educational development as compared to other districts in Nepal. Out of five districts in Rapti Zone, Rolpa has been the least performing in educational development. People would not have abilities to critically analyze, explain and look into political propaganda and therefore, would easily be manipulated. (Head teacher from a school in Rolpa)

Depriving people of educational opportunity is profoundly detrimental to peace and justice but simply providing 'more of the same' education does not look like a viable option to contribute to building peace either, since it was those who were educated that 
led the conflict. In other words, what may be essential now, as Smith and Vaux (2003) suggest, is to look more closely at the 'type' of education that is on offer and the values and attitudes it is promising. This critical perspective suggests that what may be more important is reforming the education systems in fragile states rather than working for the simple 'expansion' of existing educational provision; the major approach to 'educational development' in Nepal to date.

Many of the problems and current solutions are thus rooted in a failure to make a decisive break with the historical evolution of education in Nepal, but rather function to extend the status-quo. During the Rana oligarchy (1846 - 1950), education served as a 'tool of cultural repression' (Bush and Saltarelli 2000), and was limited to the privileged ruling class and their relatives. The Ranas had a major aversion to the extension of mass provision viewing public access to education as 'afno khuttama aafaile bancharo hannu' ('chopping off their foot with their own axe'), anticipating the role of education in enhancing public awareness thereby inviting threats to their autocratic regime. From the 1950s onward, education received increased public attention especially with the sudden growth of its 'modern' form: the Ministry of Education with its regional offices across the country. Another major attempt to accelerate educational development was the introduction of a comprehensive Educational Plan in 1971 that increased state intervention on teacher recruitment, curriculum, monitoring and supervision of schools across the country. Yet, arguably the major developments came after the 'restoration' of democracy, when millions of donor dollars poured into Nepal aiming to extend existing provision more widely.

Even though the number of schools increased by almost threefold from the Panchayat era by 2003 as a result of these ambitious plans and efforts (MOES 2005), the quality of teaching and learning continued to be poor due to the lack of adequate resources and trained workforce compounding the problems of a school system that had always been exclusive and discriminatory. The Khas groups (particularly Brahmin and Chhetris from the hilly region) had long dominated state authority and thus completely ignored the social, cultural and ethnic diversity of Nepali society by enforcing the Nepali language and Khas culture in the formal curriculum. This had long impacted on the learning abilities of children coming from minority ethnic communities and non-native Nepali 
speaking backgrounds (Ragsdale 1989), but the more recent development process only intensified this with the extension of the unequal system and aided the Khas groups controlling the state by providing additional funds for their exclusive educational projects. Even in 2001, a full decade after multiparty democracy was restored, equal rights were spelled out in the new Constitution, and educational 'development' efforts intensified, literacy rates among Brahmins, the so-called upper caste was $70 \%$ as compared with a dismal 10\% among the several low-status caste groups (Central Bureau of Statistics 2003). This was a failure of externally led development to address the country's most pressing social problems.

Youth frustration has also been an important issue in recent years. Primary enrolment increased at the surprising rate of $20 \%$ per decade compared to the $2 \%$ literacy recorded in 1951. As a measure of its success in expansion, Nepal has achieved $92 \%$ primary enrolment and adult literacy has grown to $49 \%$ so that now $70 \%$ of the youth population (15 - 24 years) are literate (World Bank 2001, 2009). However, one must ask whether these simple increases represent gains in the 'quality' of education and served the interests of the country at large or were simply 'more of the same'. There is a pervasive feeling that education today largely provides theoretical knowledge and young graduates mainly gain certificates without any substantial employment skills, a perspective that is often hidden by the statistics proffered by development agencies working in this sector. Instead, there is mounting evidence that rather than reasonably contributing to the economic life of individuals or the nation, the increase in enrollments without either (a) improvements in quality or (b) adequate employment opportunities for those 'lucky' enough to graduate, only fuel frustration and conflict. An analysis of interviews with parents and teachers confirmed that education played a complicit role in exacerbating long-standing social tensions by failing to produce graduates with life skills, nor offering them any real prospect for meaningful employment thereafter. A teacher in the eastern mountains interviewed explained:

Our education is neither scientific not it focuses on the employment needs of the people. It substantially lacks utility in practical life. Educational institutions are developed as the centers for producing graduates who largely remains unemployed. 
On the other hand, the private-public divide in education has also created tensions by reinforcing the social divide. Education unfortunately became an issue in the conflict. (A teacher from Sankhuwasabha)

In fact, a range of stakeholders in the Nepalese school system quite often recognize and condemn education for its inability to equip young people with necessary life skills and then leading them down the path of unemployed graduate youth, yet few appear to have alternative 'solutions' perhaps because education is so tightly bound up with the idea of being 'modern' - a ladder to bikas (development). Yet, despite this optimism, the state of worsening joblessness and greater uncertainty about their future, when coupled with this education producing unemployed graduates, appears to have significantly contributed to the political cause for rebellion led by the UCPN-M.

A prominent example is the All Nepal National Free Students Union (Revolutionary) (ANNFSU-R), the student wing of the UCPN-M, which primarily consisted of an educated mass of university students who were ideologically extreme and physically brutal. The ANNFSU-R played a vital role in mobilizing these discontented youth and radicalizing the revolutionary agenda across the educational sector. It is their involvement that gives additional evidence to the idea that it was the educated, yet marginalized, that, together with exacerbating historical inequalities and producing the top Maoist leadership, drove the 'People's War'.

In addition to the ANNFSU-R, there were also a considerable mass of schoolteachers and state employees who cryptically extended moral support to the Maoists and voluntarily contributed to the 'People's War' in different ways. A teacher in Kathmandu mentioned:

Within the school, the trust among fellow teachers eroded significantly. No one talked about politics of the conflict because we were afraid of being mistakenly exposed as the supporter of either of the conflicting parties. There could be spies among us. Even in the city, where one could feel reasonably safe, we pretended to be politically neutral. But we knew that almost everyone was secretly contributing [money or support] to the 'People's War'. Most interestingly, when the CPN-M entered open 
politics, we were amazed to discover that our head teacher was an advisor of the Maoist teachers union. (A teacher in Kathmandu)

As odd as it may sound, the access to education, which is taken as consensually global endeavor to extend basic rights and enhance quality of life, may actually 'harm' schools rather than doing them 'good' if both the type of education provided extends an unequal society and schools become a premier battleground for a wider social conflict. That is, even though the educational goals of literacy and numeracy are essential components of global educational campaigns, these initiatives as Harber (2004) suggests, do not occur in a vacuum - rather they serve equally the underlying purpose of instilling certain values, beliefs and principles in learners. Without an explicit attempt to challenge the status quo, these newly instilled values and beliefs, de-facto, contribute to it.

Moreover, in the context of Nepal, schools and universities were not only the centers for pure educational undertaking but also the political junctions where the critical debates surrounding state policies and people's democratic rights were rehearsed (Caddell 2007). While the economic purpose of education promised by 'development' failed to deliver, expansion and extension of schooling only served to considerably raise the political awareness of disillusioned youth, as well as provide a common meeting ground where their mutual discontent with the broken promises of the economic, 'development', and 'modernity' would crystallize in political mobilization, organizations such as ANNFSU$\mathrm{R}$ who vehemently supported the Maoists throughout the conflict.

\section{Exclusion in education}

Historically, several ethnic and caste-based groups in Nepal have been denied equal access to education. Those marginalized in particular were women, Dalits ('oppressed', 'broken' or 'crushed'), the formerly 'untouchable' castes, and the Adivasi Janajatis, the 'tribal', indigenous ethnic groups who possess their own language and cultural identities. 
Prior to the Civil Code (1963) that legally banned caste-based discrimination, Dalits were treated as 'untouchable castes' and prevented from gaining access to any kind of formal education. In the days when the only reading materials were the religious texts, the people from untouchable castes were led to believe that they would go insane even if they heard someone reading the religious texts (an insight gleaned from informal conversations with Brahmin priests in the Western hills of Nepal). Therefore, Dalits were supposed to avoid religious ceremonies that involved reading aloud of religious mantras. If they approached such events by accident, they had to cover their ears and warn pundits of their arrival so that the reading could be adjourned. Despite the abolition of such overt forms of discrimination several decades ago, the practice of 'untouchability' is still pervasive in most rural parts of the country and the caste-based prejudices frequently obstruct Dalits from gaining quality education.

Bista $(1991,72)$ argues that appreciation of 'caste distinctiveness' harks to the process of child's 'socialization' in the family where high caste parents set competitive academic expectations for their children. High level of achievements, leadership roles and uniqueness are often associated with their high caste identity whereas 'dancing, singing and sporting' generally fall in the portfolios of lower caste children. Yet, the 'period of rapid educational expansions' in terms of the number of schools established after the political change in 1950 did not mean 'a narrowing of educational disparities by caste' (Stash and Hannum 2001, 357). A head teacher from Rolpa explained the social implications of the continued caste-based exclusion in education in his school:

Education has not been easy to access for all. Education has been always favorable to the individuals from higher class [caste] whereas the lower class people have been deprived of this opportunity. Consequently, the privileged castes would gain decent professional education that allows them to attain comparatively more prestigious and better-paid employment. The people from lower class [caste] are deprived of gaining quality education [for their economic and cultural reasons] that consequently prevents them from access to the lucrative economic opportunities. The lack of excelling opportunities perpetuates their low social, cultural and economic status. (A head teacher from Rolpa District) 
Additionally, the gender-based hierarchy of Nepalese society contributed to depriving women of gaining equal access to education. Girls were educationally disadvantaged by a 'rational cost-benefit analysis' (Stash and Hannum 2001) that held that their committment to their husband's family after their marriage would mean that educational investment in daughters (viewed narrowly in terms of of long-term economic benefit to the family), was unreasonable. On the contrary, the sons who would provide support in the old age would naturally receive better attention and the best possible educational opportunities. Gender disparity is still evident at all levels of education and the percentage of girls who have had the chance to attend schools is still roughly half (32.6 percent) of the same figure for their male counterparts (61.2 percent) (Central Bureau of Statistics 2004). While the females represent more than half of the country's population, the percentages of female teachers in primary, lower secondary, and secondary level are 29, 16 and 10 respectively, whereas the percentage of female school principals across the country is less than 5 percent (Bista 2004).

Nepal's geographical terrain with uneven distribution of populations across the country also impacted on children's ability to physically get to school, another barrier to education experienced by the rural poor and thus a factor that came to reinforce exclusion. In many places around the country, young children have had to walk several hours to attend the primary school. With Nepal having a majority illiterate population means that there would be little family support or encouragement and, in the worst scenario, no attempt to educate children. A teacher interviewed in Rolpa explained a situation that is largely counterintuitive to outsiders:

Some parents come to the school and request us not to promote their children to grade six. This is because, if the child were promoted to grade six, they would have to transfer to a secondary school, which is several hours of walking from their homes. This means that the child would have to rent the accommodation away from home. This would add additional financial burden on parents and more importantly, children 
staying away from home means that the parents would no longer receive help in domestic work including agriculture.

Access to secondary education and beyond is therefore not within the reach of every Nepali child. The parents who could afford to pay for their children's higher education would potentially make their children's economic life comparatively more secure.

The process of forming 'a uniquely Nepalese identity' permeated the concept of the modern national education system that largely denied the existence of 'a dynamic tension with regional and ethnic identities' undermining the significance of indigenous language and culture (Pigg 1992, 497). Educational provision for Janajati (tribal) or Aadibasi (indigenous) children was often non-existent since Nepali, the medium of teaching and learning at schools, was not often their mother-tongue and the curricula was often too 'foreign' to engage with. As discussed above, the language-based exclusion grew remarkably during the Panchayat era and remained almost unaddressed during the postpanchayat period despite the recognition of cultural and linguistic diversity in the 1990 Constitution. While there were some efforts particularly by the international donor agencies in democratizing educational policy during the 1990s, as well as funding the production of 'mother-tongue instruction materials' (Shields and Rappleye 2008a, 269), these attempts, albeit exemplary, that could potentially contribute to the promotion of indigenous language and culture, remained far from making the bold, decisive policy break needed to signal a departure from the historical backdrop of linguistic and ethnic exclusion that had already produced a substantial pool of educated discontent. One of the 40 demands by the Maoists presented to the government before the declaration of the 'People's War' stated explicitly that 'All languages and dialects should be given equal opportunities to prosper. The right to education in the mother tongue up to higher levels should be guaranteed' (Maoist Statements \& Documents 2003), thus testifying to the connections between the prevailing condition of linguistic exclusion in Nepal and conflict. In this way, it is apparent that multifaceted exclusion in Nepal's education system played a complicit role in reproducing 'social divisions' in the form of caste, gender and ethnicity (Bush and Saltarelli 2000) to provide fertile grounds for the growth and spread of the 'People's War'. 


\section{Violence in schools}

Violence inside and outside of schools was both a cause and correlative of the conflict. The practice of corporal punishment in Nepali schools is culturally approved even though the latest amendment of the law prohibits severe punishments to children. The Children's Act (1992), though prohibiting serious maltreatment, allows minimal physical punishments for correcting children's misbehavior. Violence in schools also has a deep pedagogical link to the traditional rote-learning method. There is a saying in Nepali society - 'Ghokanti bidhya dhawanti kheti' ('Knowledge is gained through rote-learning as good grains are gained by frequent visits to the farm'). Students are asked to memorize lessons, readymade responses to questions and other texts as a dominant pedagogy. The presence of potential violence in the form of 'corrective' measure for learning reinforces comparison and normalization (Foucault 1977) of existing hierarchies. The role of the teacher is viewed more as an agent of disciplinary actions rather than a contributor of learning. The modern education system in Nepal still reveals the notions of the teacher from the pre-modern Gurukuls (Hindu religious schools) where children had to undergo severe hardships doled out by their 'master' during their education. One third of Nepali children experience physical punishment as remedial measures of disciplined upbringing at home (SAATHI 1997). Physical punishment is also a direct form of violence against children that is widely practiced in Nepali homes where "parents generally resort to threats, intimidation, fear and in some cases deprivation of food as an incentive for good behaviour' (UNICEF 2001, 17). The fear of physical punishment by teachers leads children to a 'dislike' of the school, which subsequently becomes a major cause of truancy and attrition. Children who are physically or verbally abused are likely to employ the same methods when they grow-up since the 'punishment reinforces rebellion, resistance, revenge and resentment' (UNICEF 2001). The rapid proliferation of the violent conflict (1996 - 2006) across the country can be viewed, most broadly, in the context of the nature of Nepali society where violence is customary and it was thus easily accepted, almost paradoxically, as a means of achieving social justice. 
When the 'People's War' achieved its momentum and schools were gradually dragged into the fray of the conflicting parties, the victims of corporal punishment were not only students but also teachers who were physically abused by the Maoists and the security forces in front of school children (Watchlist 2005); a situation that fundamentally changed the traditional notion of corporal punishment at schools. Since the Maoist leadership consisted of a considerable number of former teachers, the state tended to harbor suspicion and prejudice of teachers as the conflict gathered momentum. Such a state-perceived stereotype underpinned the proclivity for state caused violence directed at teachers. As one respondent revealed:

The state believed and embraced a policy accordingly, that every 10 people they killed from the educational sector, they would eliminate 6 rebel commanders. In other words, the state firmly believed that education sector or the teachers were the key players of the conflict who invited and nurtured the conflict. (A teacher from Rolpa)

In this context, violence and coercion became an everyday experience for children and teachers during the conflict. Liwang village, the headquarters of Rolpa district was fenced inside with barbed wire and the district administration imposed a curfew in the town during night. Children from outside the town would have to pass through several security checkpoints on the way to and from their schools. Teachers and students mentioned that the security forces would often abuse them physically during the routine security checks. Some schools were located in the war zone so that it was virtually impossible to distance children from the acts of violence (one vivid description of this is presented in the next section).

School children also constantly feared abduction and forced recruitment in the rebel army or being apprehended by the state authority (Watchlist 2005). The Royal Army would launch aerial attacks on the school premises during the Maoist-organized mass meetings. This would frequently cost innocent lives including those of young school children. The Watchlist report also documents a number of incidents where state forces 
would requisition school premises to use them as military barracks. Confirming this, one teacher interviewed recalled that:

... local police issued a notice for the higher secondary school in Martadi, in Bajura district, to vacate the school facility in early 2002. Subsequently, teachers moved their classes into a dilapidated building belonging to a nearby hospital, which was in jeopardy of collapsing.' (Watchlist 2005, 22)

During the emergency, the interference from the Royal Nepal Army was much worse than that of the rebels. The soldiers would enter the school premises in the name of providing security to the school and start peeping through the classroom windows while the teachers would be delivering their lessons. This made teaching and learning extremely difficult. Most of my staff and students were terrified due to the presence of the armed soldiers in the school. (A head teacher from Sankhuwasabha)

Violence in schools also included extortion of money by the Maoists and in extreme cases, teachers were physically abused and even killed for noncompliance to the rebel demands or non-cooperation with the dictates of the security forces.

\section{Impact of the armed conflict on school education}

While teachers, students, and parents experienced the conflict in diverse ways, the effects generally resonated collectively or spread from one actor to the next. Since the genesis of the 'People's War' occurred in a complex historical backdrop of socio-political conditions, its expansion and popularity needs to be viewed in the similar context, in which education became both a cause and victim of the violence, making it often quite difficult to make explicit links between the wider socio-political conflict and the micro level violence occurred in the educational settings.

The decade-long conflict forced teachers to operate in a perpetual state of terror and under extreme pressure from the armed groups that eroded their professional motivation 
and the quality of their personal life. Teachers in the rural communities became proficient with a new 'vocabulary of terror' (Suárez-Orozco 1987) such as 'mandatory donations', 'displacement', 'abduction', 'forced participation', 'torture', 'banda' [closure], 'political education', 'army check points' and so forth. A schoolteacher in Udaypur described his classroom experience during the conflict, including some of the impacts on curriculum in particular:

We had to be very cautious and restricted about what we spoke. We could not discuss all the aspects of Social Studies. We could not mention about contemporary incidents even though they were related to social issues we were teaching. For our own safety, we had to be very careful in using the words while teaching and keep away from any kind of political flavor during our lessons and while interacting with students. It was such a painful professional experience.

Like other Nepalis living in the rural areas, teachers grew accustomed to the 'routinisation of terror' (Pettigrew 2003). Even though the propensity of explicit violence on educational stakeholders has receded, the decade-long 'routinisation' of the 'culture of terror' still prevails in the present context of political uncertainty. A significant portion of the teaching force was debilitated and traumatized during the decade-long reign of torture, extortion and intimidation (INSEC 2007). The terror of 'mandatory donations' and compliance with the demands of the conflicting parties caused deep psychological neurosis in teachers, something that came up frequently, although largely implicitly in the field interviews.

The constant sense of fear during the conflict forced many teachers to flee their homes either to seek sanctuary in the district headquarters or to join the war as the only option available. By 2004, an estimated 3,000 teachers had been displaced from the schools in the rural areas, directly impacting on an estimated 100,000 students' education (Thapa and Sijapati 2004). By the time of the ceasefire, the total number of teachers killed by the Maoists and the state was 145 (INSEC 2007). Given the evidence that civil wars have long-term effects on the lives of survivors (Ghobarah, Huth, and Russett 2003), the end of violence does not signal a return to normalcy. The impact of war on the teaching force 
is 'often more qualitative than quantitative' (Buckland 2005, 14), a conclusion that is clearly indicated by the fact that the war victims in Nepal's educational sector described enduring pain, both physically, emotionally, and psychological. One of the in-service teachers of this study, brutally assaulted by the Maoists, explained the on-going legacy of his experiences:

I cannot walk more than 15 minutes. If there is a loud noise around and if any one tells me that there are Maoists around, I get mortified. I feel so weak and cannot eat properly. I have lost all the motivation and enthusiasm to work. I am still on medication. I always feel terrified without any reason. If I recall that incident, I feel dizzy and start sweating. (A teacher in Doti)

The impact of the conflict on school head teachers was particularly harsh because of the psychological stress created by the constant challenge of trying to maintain equilibrium in relations between the Maoists and state authorities. Their diffuse roles as a head teacher conceivably linked them with communities, rebel groups, and the state authority. Moreover, new demands on head teachers' for 'accountability' by an emerging 'new state' paradigm (school-based management, etc.) resulted in perplexity and substantial dilemmas over issues of professional loyalty. At the same time, the security and wellbeing of their teaching staff and children was paramount in the situation where thousands of school children were being abducted and several schools had been turned into battlefields (Child Workers in Nepal Concerned Centre 2006). Head teachers were also receiving an enormous amount of pressure from parents which one head teacher interviewed described in the following way:

After my school was bombed, the parents questioned why the incident took place or why the school was bombed. They blamed me for not paying the rebels the donation as per their demand. It was not true at that time. I informed the parents that I was paying them enough. But some parents were unhappy about the donation payments to the rebels as they objected to the funding of rebel activities with the money they paid 
for quality education for their children. (The Head teachers in a private school in Kathmandu)

Parents demanded that the school be responsible for any serious incidents that might occur in the school and subsequently could cause harm to their children. If any cross firing occurred or bombs exploded in the school as a result of the school management's non-compliance to the Maoists' call for the school closure, we would be held accountable. This damaged the teachers' morale and their motivation to work and I was helpless as the education sector was entirely powerless and the state in those times was crumbling and the security situation was vulnerable. (A Head teacher in a private school in Udaypur)

In other interviews, many head teachers recalled the intense psychological pressure experienced as a result of threatening phone calls and the letters received from one or more of these conflicting parties.

Similarly, the impact on children's education was remarkable due to the massive scale of internal displacement (Raj 2004, 148), closure of private schools in the rural areas (Caddell 2006), and frequent bandas (strikes) called by the Maoists as a tactic of paralyzing state functions (Thapa and Sijapati 2004). It is estimated that 8,000 children were orphaned during the conflict and over 32,000 were abducted either for political campaigns or recruitment in the rebel army. An estimated 475 children lost their lives during the conflict whereas, 562 sustained injuries either in the crossfire or explosions (Child Workers in Nepal Concerned Centre 2003). One student from Doti explained:

In October 2003, the armed security forces attacked my school. On that day, a group of Maoists had organized a cultural program in our school. They were not particularly armed. In fact, these artists were students like us who were brought from another school to perform a cultural show at our school. But they were members of the Maoist cultural groups. The Maoists forced all students to view their cultural show and would not let anyone leave the school premises without their permission. Before the show 
began, there was an explosion near the school. Suddenly, armed soldiers surrounded our school and started shooting at us recklessly. Two of the children who were on their way home were killed on the spot. Other three children were shot inside the school. I was also hit on my leg and fell on the floor inside the canteen. I screamed for water but there was no one around. The soldiers who had gone mad locked all others inside the classrooms and shooting randomly at everyone they found suspicious. Eleven young people were killed during this attack - of the dead, 6 were my friends. I fell unconscious. When I opened my eyes, I found myself on the hospital bed. I realized that I was later airlifted to the regional hospital. Despite the long treatment, doctors could not take the bullet out of my leg for several months. My leg will not be recovered and I walk with this bamboo crutch. (A seventeen-year-old boy in Doti)

For secondary school children in the outlying regions, it was virtually impossible to remain 'politically neutral' from the mounting 'rebellion' even if they could escape the Maoist recruitment campaigns. Young students who experienced these dangers revealed that the mounting conflict resulted in the decline of their aspirations and rising doubts about the futility of life and banality of school education.

The fear generated by the violent conflict also altered the way people moved around in their communities (Pettigrew 2003). Clearly, public mobility suffered from self-imposed restriction as an understandable precaution to being caught in an unpredicted occurance of violence in the village. For teachers and children, especially in the mountains where schools are generally located, travelling to and from schools was a dangerous undertaking. Parents of teenage children would always be worried and troubled about their children's safety while at school. While the risk of being caught in the crossfire was pervasive, young people equally feared the risk of forced recruitment in the rebel army, abduction, or even being arrested by the security force as a Maoist suspect. As one parent lamented: 
The soldiers in the camps would observe our children play on the school playgrounds with their binoculars. Anyone who was able to jump and looked physically fit would be arrested as a Maoist suspect. (A parent in Kapilvastu)

We were extremely terrorized by the risk of our children being nabbed by the armed groups on their way to and from school. I could not live with the everyday fear of losing my son. So, I took him out of school and sent him to Malaysia for work. (Another parent during a group discussion in Kapilvastu)

Perhaps an even more severe impact of the armed conflict has been the hyperpoliticization of the school system. During fieldwork, I personally witnessed a branch office of a non-governmental organization, working in the education sector and with children's rights, attacked by children (aged between 10 and 16 years old) from the nearby secondary school. Ostensibly, the cause of the protest was the local head of the NGO trying to politically 'influence' the children groups and the schools they were working with. The children burnt tires on the road to block the traffic and tried to vandalize the office premises of the NGO. The police were deployed to disperse the crowd but the disturbance (and likely fear of later retribution) proved too much for them to tackle. Teachers merely waited for children to return to their classes. When asked whether children sought official permission to go out of school to participate in the demonstration, the head teacher and other teachers looked at each other and reacted with dismay. The head teacher explained later that the students were 'empowered' to such an extent that they could make their own choices and did not seek permission to carry out political protests. It is worth pointing out how the use of 'empowerment' - a trope of educational 'development' - had come to be utilized in ways that reinforced the conflict, perhaps some indication of the extent to which rising political expectations and messages of progress originally put forth in the arena of limited development activities and/or education had spilled, often violently, beyond those narrow bounds. 


\section{Conclusion: envisaging the future}

In the elections of the Constituent Assembly held in April 2008 to draw up a new national Constitution, the former rebel party UCPN-M, appeared as the largest party winning 50 percent of the seats (120 out of 240) in the first past the post system, securing almost one third of the total votes (Election Commission of Nepal 2008). Their popularity was demonstrated not only in the rural areas but also in the capital where they were able to win 7 out of 15 seats. Nepal thus made history with the World's first elected Maoist government. However, in a surprise move, the UCPN-M renounced power just over a year later citing executive interference by the president against the government's decision to dismiss the Chief of the Nepali Army; a man considered by the guerillas to be central to the Country's descent to brutality (Raman 2009). The Maoist demands of 'civilian supremacy' and the President's refusal to accept this has left the country, yet again, in the state of political turmoil cum stagnation, thereby risking the future of Nepal's peace process (Chandrasekharan 2009). The Maoist's plan to bring in substantial structural change across the public sector remains therefore uncertain. At the same time, donor led educational development has continued in largely the same manner, apparently underpinned by the belief that education can only have positive effects. In this way, the possibilities of a new educational reform agenda rooted in a deeper understanding of the connections between schooling, 'development' and conflict seem to have been lost.

Notwithstanding this lost opportunity, the decade long 'People's War' has significantly improved political awareness among the public and initiated a much-needed discussion of Nepal's future. Young people in rural Nepal are hugely interested to take part in peace-building but they are currently struggling to identify ways in which they could contribute within their communities (Pherali 2007). It is, for example, deeply problematic that education is still conceptualized in terms of its economic rather than social value. Perhaps peace-building education embedded in 'inter-ethnic (and intercaste) economic development projects' (Bush and Saltarelli 2000) can provide young people as well as communities with opportunities to play positive roles in bridging the dividing lines of the past. As one of the few institutions where diverse groups mix, education and schooling could become a key venue for such efforts. 
Whilst such action holds promise, there is a real challenge in Nepal to understand and address the 'negative face' of education (Bush and Saltarelli 2000) which is deeply embedded in a socio-cultural system that has played a role in producing individuals who recognize armed struggle as a legitimate route to social change. Guiding educated, yet frustrated youth towards progressive (peaceful) nation-building projects is hampered further by the symbolic and material violence of a pervasive caste system, deeply-rooted practices of gender discrimination and an educational system that struggles to embrace diversity of social class and ethnicity. In this sense, as sites that perpetuate historic deficiencies and generate new regressive norms, schools may be best thought of as part of the persistence of instability in Nepal.

International support for substantial reform is still essential but the conflict and subsequent peace deal suggest that such efforts should focus more on listening to local voices and strengthening development solutions that reflect the voices of those who have lived the brutality of inequality and the terror of armed conflict. Rather than promoting and enforcing generic development models that have migrated from vastly different contexts but which are part of the liberal, global, development agenda (Carney and Bista 2009), peace-building efforts in education need to start with those who have survived the trauma of war and be 'founded on their experiences and capacities' (Bush and Saltarelli's 2000, 27).

Whether the 'development' apparatus (meaning government, donors and the values on which they base their cooperation) is configured in ways that make it possible to rethink change processes remains to be seen. Whilst the current road map for peace appears to reflect a new national agenda (where the parliamentary parties have agreed on a core program leading to parliamentary democracy, an elected head of state and a timetable for a new constitution), the implementation of sector-level reform is shaped deeply by loosely-articulate visions that combine issues of access, equality, quality, diversity, relevance and excellence (e.g. International Alert 2006); all of which must be administered within the resource-constrained context of one of the World's poorest and most traumatized societies. Thus the prospects for a 'new Nepal' look increasingly bleak as long as 'development' in the Government/Western-led sense continues to drive national policy. Because the linkages between 'development', conflict, and education are 
imprecise, spaces remain for dominant voices to assign the current turmoil in Nepal to poor 'governance', 'tradition' or Nepali 'recalcitrance'. While seeds of truth in each will continue to allow these excuses to flourish, these aspects of 'Nepal' have not led to open civil war and social disintegration until massive donor intervention and democracy came to the fore two decades ago.

These concerns exercise many within Nepal, and not only the Kathmandu elite. What should have been done differently? What options were available when a Country with many dehumanizing social norms attempted to resolve these via full-scale military conflict? Why was the violent route so successful and how did this manage to inspire, coerce and crush so many young people in such a short time? Why did the State resort to politicizing schools but primarily via the discredited discourse of monarchy, obligation and service? How could schools be remade in order to contribute to a just society? Such questions remain unanswered, suggesting that the struggle for the soul of Nepal is far from over.

\section{Notes on contributor}

Tejendra J. Pherali (T.Pherali@1jmu.ac.uk) is a Senior Lecturer at Liverpool John Moores University, UK. His research focuses on the role of youth in education and conflict, dynamics of peace-building, and possibilities for a national level, community-led peace-building program in Nepal.

\section{References}

Amnesty International. 2005. Nepal: Children caught in the middle. Kathmandu: Amnesty Interntional.

Bhattarai, B. R. 2003. The political economy of the People's War. In The people's war in Nepal: Left perspectives, eds. A. Karki and D. Seddon., 117 - 164. New Delhi: Adroit Publishers.

Bista, D. B. 1991. Fatalism and development: Nepal's struggle for modernization. New Delhi: Orient Longman. 
Bista, M. 2004. Review of research literature on gilrls' education in Nepal In UNESCO Kathmandu Series of Monographs and Working Papers: No 3. Kathmandu: United Nations Educational, Scientific and Cultural Organization.

Bohara, A. K., N. J. Mitchell, and M. Nepal. 2006. Opportunity, democracy, and the exchange of political violence: A subnational analysis of conflict in Nepal. Journal of Conflict Resolution 50, no. 1:108-128.

Buckland, P. 2005. Reshaping the future: Education and postconflict reconstruction. Washington, D.C.: The World Bank.

Bush, K. D., and D. Saltarelli. 2000. Two faces of education in ethnic conflict: Towards a peacebuilding education for children. Florence: UNICEF, Innocenti Research Centre.

Caddell, M. 2006. Private schools as battlefields: contested visions of learning and livelihood in Nepal. Compare: A Journal of Comparative Education 36, no. 4:463-479.

. 2007. Education and change: A historical perspective on schooling, development and the Nepali nation-state. In Education and Social Change in South Asia, edited by K. Kumar and J. Oesterheld. New Delhi: Orient Longman.

Central Bureau of Statistics. 2003 Population Monograph of Nepal. In vol. 1. Kathmandu: National Planning Commission Secretariat.

- 2004. Nepal living standard survey 2003/2004. Kathmandu: Central Bureau of Statistics.

Chandrasekharan, S. 2009. NEPAL: Frustrated maoists go on the offensive: Update no. 209. http://www.southasiaanalysis.org/notes6/note550.html.

Child Workers in Nepal Concerned Centre. 2003. The state of the rights of the child in Nepal. Kathmandu: Child Workers in Nepal Concerned Centre.

- 2009. Situation of education in Nepal. Child Workers in Nepal Concerned Centre 2006 [cited 06/12/2009 2009]. Available from http://www.cwin.org.np/press_room/fact_sheets/fact_cic.htm.

Clandinin, D. J., and F. M. Connelly. 2000. Narrative inquiry: Experience and story in qualitative research. San Francisco, CA: Jossey-Bass. 
Davies, L. 2004. Education and conflict: Complexity and chaos. London:

RoutledgeFalmer.

. 2005. Schools and war: Urgent agendas for comparative and international education. Compare: A Journal of Comparative Education 35, no. 4: 357-371.

Deraniyagala, S. 2005. The political economy of civil conflict in Nepal. Oxford Development Economics 33, no. 1: 47-62.

Dhital, T. 2006. Sashastra dwandako chapetama balbalika: Sashastra dwandaka kramma mritu, ghaite, pakrau tatha apaharanma pareka balbalikako biwaran 1996 - 2006 (English translation: Children caught in the armed conflict: Details of the children dead, wounded, arrested and adducted during the armed conflict 1996-2006) Kathmandu: CWIN Nepal.

Do, Quy-Toan, and L. Iyer. 2007. Poverty, social divisions and conflict in Nepal. In World Bank Policy Research Working Paper 4228, May 2007. Washington, D.C.: World Bank.

Foucault, M. 1977. Discipline and punish: The birth of the prison. London: Penguin Books.

Ghobarah, H. Adam, P. Huth, and B. Russett. 2003. Civil wars kill and maim peopleLong after the shooting stops. American Political Science Review 97 (2):189-202.

Harber, C. 2004. Schooling as violence: How schools harm pupils and societies. Abingdon: RoutledgeFalmer.

Hutt, M. 2004. Introduction: Monarchy, democracy, and maoism in Nepal. In Himalayan 'people's war': Nepal's maoist rebellion, ed. M. Hutt., 1 - 20. London: C. Hurst \& Co. (Publishers) Ltd.

INSEC. 2007. Human rights year book. Kathmandu: Informal Sector Service Centre.

International Alert. 2006. Education for All - Nepal. Kathmandu: International Alert/Embassy of Finland.

Kumar, D. 2003. Consequences of the militarized conflict and the cost of violence in Nepal. Contributions to Nepalese Studies 30, no. 2: 167-216.

- 2005. Proximate causes of conflict in Nepal. Contributions to Nepalese Studies 32, no. 1: 51-92. 
Maoist Statements and Documents. 2003. In The people's war in Nepal: Left perspectives, ed. A. Karki and D. Seddon., 183 - 287. New Delhi: Adroit Publishers.

MOES. 2005. Nepal in educational figures. Kathmandu: Ministry of Education and Sports of Nepal.

Murshed, S. M, and S. Gates. 2005. Spatial-horizontal inequality and the Maoist insurgency in Nepal. Review of Development Economics 9, no. 1: 121-134.

Neupane, Govinda. 2003. The Maoist movement in Nepal: A class perspective. In The people's war in Nepal: Left perspectives, ed. A. Karki and D. Seddon., 291 - 314. New Delhi: Adroit Publishers.

Onta, P. 1996 Ambivalence denied: The making of Rastiya Itihas in Panchayat era textbooks. Contributions to Nepalese Studies 23, no. 1: 213-254.

Pettigrew, J. 2003. Living between the maoists and the army in rural Nepal. Himalaya XXIII, no. 1: 9-20.

Pherali, T. J. 2007. The role of youth in peace building and community decision-making. Kathmandu: Search for Common Ground Nepal.

Pigg, S. L. 1992. Inventing social categories through place: Social representations and development in Nepal. Comparative Studies in Society and History 34, no. 3: 491513.

Pyakurel, S. 2006. 'Kranti' ra 'Shanti' ko chyapoma manabadhikar [Human rights in between the rebellion and peace]. Himalkhabar Patrika [Bimonthly], 13-27 Feb, 55.

Ragsdale, T. A. 1989. Once a hermit kingdom: Ethnicity, education and national integration in Nepal. Delhi: Manohar Publications.

Raj, P. A. 2004. Maoist in the land of Buddha: An analytical study of the maoist insurgency in Nepal. Delhi: Nirala Publications.

Raman, B. 2009. Nepal: What next? , http://www.southasiaanalysis.org/papers32/paper3171.html.

SAATHI. 1997. A National Survey on Violence agaisnt Women and Girls in

Nepal. Kathmandu: The Asia Foundation. 
Sharma, R, and B. Khadka. 2006. Impact of armed conflict in Education. Kathmandu: Education Journalists Group, Nepal.

Shields, R. and J. Rappleye. 2008a. Differentiation, development, (Dis)Integration: Education in Nepal's 'People's War'. Research in Comparative International Education, 1, http://dx.doi.org/10.2304/rcie.2008.3.1.91.

- 2008b. Uneven terrain: educational policy and equity in Nepal. Asia Pacific Journal of Education 28, no. 3: 265-276.

Silverman, D. 2009. Doing qualitative research 3ed. London: Sage.

Simkhada, D. 2006. Kshikshaka lagi shanti [Peace for education]. Himal Khabarpatrika [Himal Quartly], 13-27 Feb, 63-78.

Smith, A., and T Vaux. 2003. Education, conflict and international development London: Department for International Development.

Sommers, M. 2007. Children, education and war: Reaching education for all (EFA) objectives in countries affected by conflict. World Bank 2002 (cited 29 December 2007 2007). Available from http://www.wds.worldbank.org/WDSContentServer/WDSP/IB/2002/10/12/00009 4946_02091704130527/Rendered/PDF/multi0page.pdf.

Stash, S., and E. Hannum. 2001. Who goes to school? Educational stratification by gender, caste, and ethnicity in Nepal. Comparative Education Review 45, no. 3: 354-378.

Suárez-Orozco, J. 1987. The treatment of children in the 'Dirty War': Ideology, state terrorism and abuse of children in Argentina. In Child survival: Anthropological perspectives on the treatment and maltreatment of children, ed. N. ScheperHughes., 227 - 246. Amsterdam: Reidel.

Tawil, S., and A. Harley, eds. 2004. Education, conflict and social cohesion. Geneva: UNESCO International Bureau of Education.

Thapa, D. 2003. The Maobadi of Nepal. In State of Nepal, ed. N. M. Dixit and S. Ramachandran., 77 - 99. Kathmandu: Himal Books.

Thapa, D., and B. Sijapati. 2004. A kingdom under siege: Nepal's maoist insurgency, 1996 to 2004. London: Zed Books Ltd. 
. 2004. Understanding the causes of the 'People's War'. In A kingdom under siege.

Kathmandu: the printhouse.

The Worker. 1996. The historic Initiation and After. The Worker (2), http://cpnm.org/worker/issue2/w2_1p.htm.

Tomlinson, K., and P. Benefield. 2005. Education and conflict: Research and research possibilities. Berkshire: National Foundation for Educational Research.

UNICEF. 2001. Corporal punishment in schools in South Asia: Submitted to the committee on the rights of the child, day of general discussion on violence against children 28 September 2001. Kathmandu: UNICEF Regional Office for South Asia.

Verma, A. S., and G. Navlakha. 2007. People's war in Nepal: Genesis and development. Economic and Political Weekly:1839-1843.

Watchlist. 2005. Caught in the middle: Mounting violations against children in Nepal's armed conflict. New York: Watchlist on children and armed conflict.

World Bank. 2001. Nepal: priorities and strategies for education reform. Kathmandu: The World Bank. . 2009. Nepal: Bringing the poorest into schools. The World Bank 2009 [cited 28

November 2009]. Available from http://www.worldbank.org.np.

\footnotetext{
${ }^{\mathrm{i}}$ The major national dailies of Nepal (The Kantipur, The Kathmandu Post, The Himalayan Times - all available online www.kantipuronline.com, www.nepalnews.com, www.thehimalayantimes.com) frequently reported about the attacks, abductions and extortion in schools during the decade of conflict (1996-2006).

ii These districts represented diverse socio-political contexts and were affected in diverse ways during the conflict. Rolpa was the origin of the 'People's War' and identified as a district 'highly affected' by the conflict. Similarly, Doti a far western district provided a case school caught in some of the heaviest crossfire of the decade. The Kathmandu valley, being the capital, remained comparatively safer but the schools experienced direct violence in various ways. Kapilvastu, a bordering district to India on the southern flatlands, was chosen for its additional characteristic of recently being a region of ethnic violence and Madheshi nationalism. Udaypur has been a link between the eastern mountains and the southern plain during the conflict and received a large number of internally displaced people from the neighbouring districts in the northern mountains. Finally, Sankhuwasabha, a remote, eastern mountainous district bordered with Tibet offered a special geographical terrain for the conflict. Given this diverse choice of field sites, the findings are thought to be more representative than other studies that focus on a single district or development region.
} 